\title{
Morphological variability and teratology of Palearctic freshwater Harpacticoida (Crustacea: Copepoda)
}

\author{
E.S. Kochanova, E.B. Fefilova \\ Institute of Biology of Komi Scientific Centre of the Ural Branch of the Russian Academy of Sciences, \\ Kommunisticheskaya,28, Syktyvkar 167982,Russia.E-mail: Ko4anova@mail.ru
}

ABSTRACT: The variability of morphological characteristics of ten populations of the freshwater harpacticoid species Canthocamptus staphylinus are described. The most variable morphometric indices (ratios of length-to-width of caudal rami and spines on the fifth leg exopod), body size, and important quantitative morphological characters (the number of spinules on the anal operculum) have been analyzed. The morphological variability of Bryocamptus (Arcticocamptus) cuspidatus, Moraria insularis, and $M$. mrazeki has been studied as well. Data on teratology like body asymmetry, deformations of morphological structures and transsexual mutations have been summarized for: Atthyella (Neomrazekiella) nordenskjoldi, A. (N.) northumbrica trisetosa, Pesceus schmeili and C. staphylinus. These variations and abnormalities in the studied specimens are assumed to be caused by geographical isolation of populations and different environmental conditions. How to cite this article: Kochanova E.S., Fefilova E.B. 2017. Morphological variability and teratology of Palearctic freshwater Harpacticoida (Crustacea: Copepoda) // Invert. Zool. Vol.14. No.2. P.148-153. doi: 10.15298/invertzool.14.2.08

KEY WORDS: Harpacticoida, Copepoda, Canthocamptus staphylinus, morphological variability, morphological abnormalities, teratology.

\section{Морфологическая изменчивость и тератология палеарктических пресноводных Harpacticoida (Crustacea: Copepoda)}

\section{Е.С. Кочанова, Е.Б. Фефилова}

Институт биологии Коми Научного иентра Уральского отделения Российской академии наук, ул. Коммунистическая, 28, Сыктылвкар 167982, Россия. E-mail: Ko4anova@mail.ru

РЕЗЮМЕ: Рассмотрена морфологическая изменчивость пресноводной гарпактикоиды Canthocamptus staphylinus из десяти популяций. Учитывались наиболее вариабельные признаки вида: морфометрические индексы (размер тела, относительные длины каудальных ветвей и щетинок на экзоподите пятой пары ног), а также количественная морфологическая характеристрика (число шипиков на анальной пластинке). Приведены некоторые сведения о морфологической изменчивости других видов: Bryocamptus (Arcticocamptus) cuspidatus, Moraria insularis и M. mrazeki. Обобщены данные о случаях уродств, отмеченных нами у гарпактикоид: Atthyella (Neomrazekiella) nordenskjoldi, A. (N.) northumbrica trisetosa, Pesceus schmeili и $C$. staphylinus. К тератологическим отклонениям относили асимметрию тела, изменения формы морфологических структур и внешние проявления транссексуальных 
мутаций. Морфологическая изменчивость и уродства исследованных гарпактикоид предположительно обусловлены географической изоляцией популяций и воздействием различных экологических факторов.

Как цитировать эту статью: Kochanova E.S., Fefilova E.B. 2017. Morphological variability and teratology of Palearctic freshwater Harpacticoida (Crustacea: Copepoda) // Invert. Zool. Vol.14. No.2. P.148-153. doi: 10.15298/invertzool.14.2.08

КЛЮЧЕВЫЕ СЛОВА: Harpacticoida, Copepoda, Canthocamptus staphylinus, морфологическая вариабельность, морфологические уродства, тератология.

\section{Introduction}

It is known (Borutsky, 1952; Wells, 2007) that intraspecific and intrapopulation diversity of harpacticoid copepods is expressed through the variability of morphological structures like body segmentation, structure of legs, antennules and caudal rami, as well as dimensional and morphometric characteristics. Furthermore, an insufficient amount of particular information on this subject may complicate the taxonomy of harpacticoids and hamper understanding of their phylogenetic relationships.

The main goals of this work are to investigate the phenotypic intraspecific diversity of some freshwater harpacticoids and to compare available data of the morphological abnormalities among these copepod crustaceans in the European North of Russia.

\section{Materials and methods}

The material for the research was collected from different ponds at various times between 1969 and 2016 by authors and their colleagues. For studies of phenotypic diversity of Canthocamptus staphylinus Jurine, 1820 samples were taken from an unnamed pond and an unnamed pool in Syktyvkar $\left(61^{\circ} 40^{\prime} \mathrm{N}, 50^{\circ} 49^{\prime} \mathrm{E}\right)$, from Nuyvchim Reservoir $\left(61^{\circ} 23^{\prime} \mathrm{N}, 50^{\circ} 45^{\prime} \mathrm{E}\right)$, from the Unya River $\left(61^{\circ} 35^{\prime} \mathrm{N}, 58^{\circ} 02^{\prime} \mathrm{E}\right)$, from an unnamed water body on Vaygach Island, from unnamed ponds in Samara $\left(53^{\circ} 11^{\prime} \mathrm{N}, 50^{\circ} 07^{\prime} \mathrm{E}\right)$, from Orlov pond in St. Petersburg (Russia), from Pääjärvi Lake $\left(61^{\circ} 04^{\prime} \mathrm{N}, 25^{\circ} 08^{\prime} \mathrm{E}\right)$, (Finland), from Geneva Lake $\left(46^{\circ} 27^{\prime} \mathrm{N}, 06^{\circ} 31^{\prime} \mathrm{E}\right)$ (Switzerland), and from Vörtsjärv Lake (57 $\left.40^{\prime} \mathrm{N}, 26^{\circ} 40^{\prime} \mathrm{E}\right)$ (Estonia) and Vänern Lake (58 $55^{\prime} \mathrm{N}, 13^{\circ} 30^{\prime} \mathrm{E}$ ) (Sweden). We measured 148 individuals of C. staphylinus and 35 character- istics to determine the patterns of interspecies variability (Fig. 1).

To investigate variability of other species and teratology of harpacticoids, samples were taken from Glubokoe Lake in Moscow region $\left(55^{\circ} 45^{\prime} \mathrm{N}, 36^{\circ} 30^{\prime} \mathrm{E}\right)$, and water bodies of the North-East of Russia: Bolshaya Lahorta Lake $\left(66^{\circ} 41^{\prime} \mathrm{N}, 63^{\circ} 54^{\prime} \mathrm{E}\right)$, Ozernaya Lake $\left(64^{\circ} 50^{\prime} \mathrm{N}\right.$, $\left.59^{\circ} 14^{\prime} \mathrm{E}\right)$, a lake in Dolgiy Island $\left(69^{\circ} 16^{\prime} \mathrm{N}\right.$, $\left.59^{\circ} 05^{\prime} \mathrm{E}\right)$, lakes in the Pechora River Delta $\left(68^{\circ}\right.$ $14^{\prime} \mathrm{N}, 53^{\circ} 51^{\prime} \mathrm{E}$ and $\left.68^{\circ} 06^{\prime} \mathrm{N}, 53^{\circ} 31^{\prime} \mathrm{E}\right)$, Lopyu Lake $\left(61^{\circ} 41^{\prime} \mathrm{N}, 54^{\circ} 54^{\prime} \mathrm{E}\right)$, the Shugor River $\left(63^{\circ} 11^{\prime} \mathrm{N}, 54^{\circ} 14^{\prime} \mathrm{E}\right)$. By “teratology” we mean study of inherent morphological deviations from normal development of individuals.

Samples were collected with hand nets (the mesh size is about $100 \mu \mathrm{m}$ ). For the purpose of identification, morphometric studies and illustrations a Leica DM 4000B microscope with micrometer eyepiece scale and drawing tube was used. For species identification, the identification guides of E.V. Borutsky (1952) and J.B.J. Wells (2007) were consulted. Species names were brought in line with the World Register of Marine Species (WoRMS) (http:// www.marinespecies.org/). Statistical analyses, Kruskal-Wallis and Kolmogorov-Smirnov tests, of the different indexes was carried out with the Statistica 7.0.

\section{Results}

\section{Morphological variability}

The body length, the number of spinules on the anal operculum and the ratios of lengths of spines on the fifth leg (P5) exopod of C. staphylinus appeared to be particularly variable among the studied populations (Fig. 1). Based on the surveys of all the varying characteristics, 


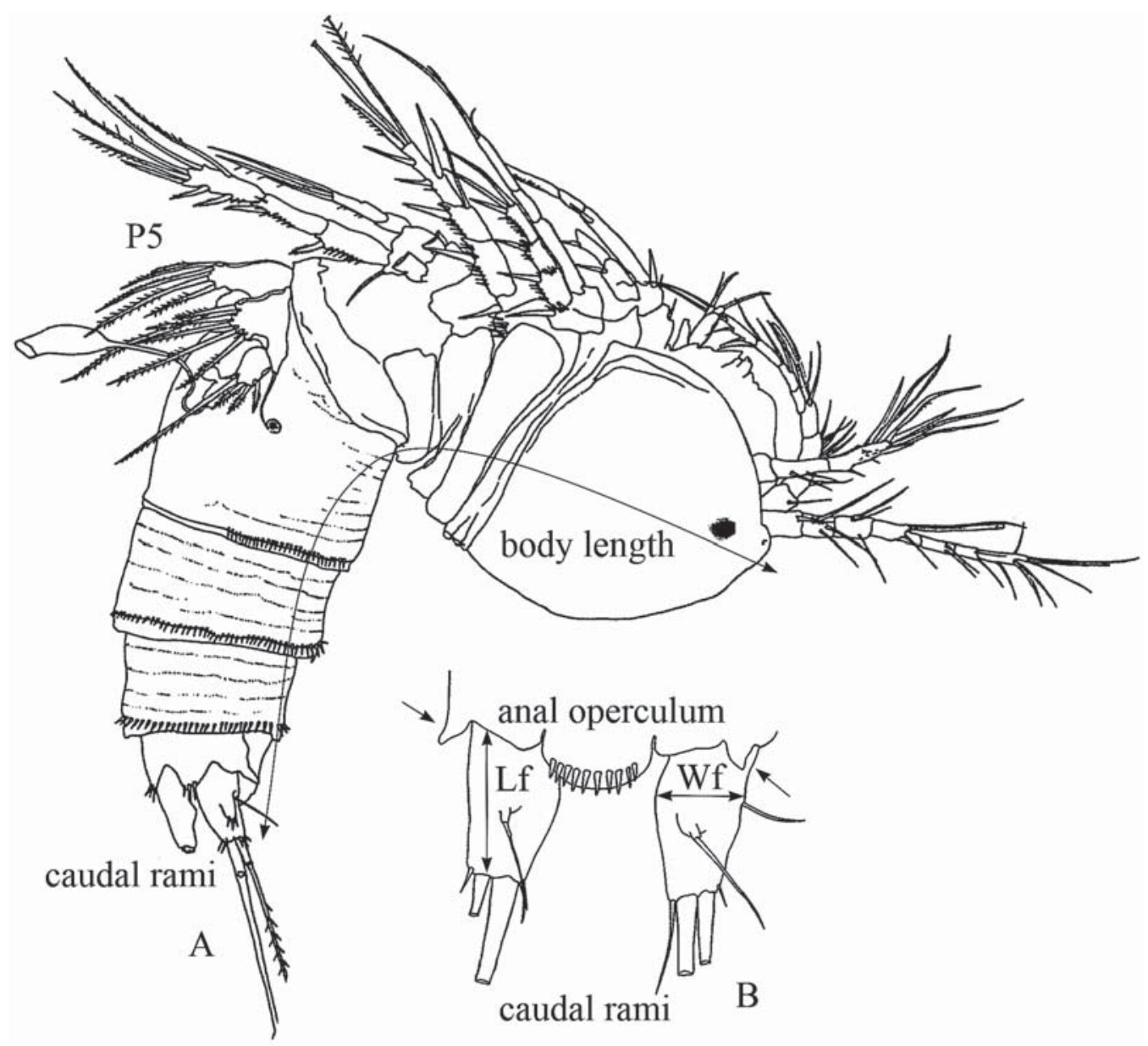

Fig. 1. Female of Canthocamptus staphylinus from the unnamed pond in Syktyvkar. A - general view, B - dorsal view of caudal rami. Some from used measurements are shown. Arrows indicate the analyzed measurements. P5 - the rudimental fifth leg.

Рис. 1. Самка Canthocamptus staphylinus из пруда в г. Сыктывкаре. А - общий вид, В — каудальные ветви дорсально. Показаны некоторые измерения для расчета морфометрических индексов. Р5 Ï рудиментарная нога пятой пары.

seven morphometrical indices of the length ratios were calculated (caudal rami length-towidth ratio and six indices of the spinnules length on the P5). Only four indices out of seven were statistically significant (by KolmogorovSmirnov and Kruskal-Wallis Tests, $\mathrm{p}<0.05$ ) for different populations, namely: caudal rami length-to-width ratio and three indices of the spinulae length on the P5. The morphological expression of these characteristics on females divided the populations into two groups. The populations of the Orlov pond, lakes Vörtsjärv, Pääjärvi, Geneva, and lake on Vaygach Island constitute the first group, while the second group includes the populations from the water bodies in Syktyvkar and the Nuyvchim Reservoir (the Sysola River basin).

In addition, examples of morphological variability were found in a population of Bryocamptus (Arcticocamptus) cuspidatus (Schmeil, 1893) from the known eastern border of its area in Bolshaya Lahorta Lake (Fig. 2A, B). Variation was also expressed in the caudal rami structure of Moraria insularis Fefilova, 2008 (Fig. 2C), collected from an unnamed lake on the Dolgy Island, and from Moraria mrazeki 


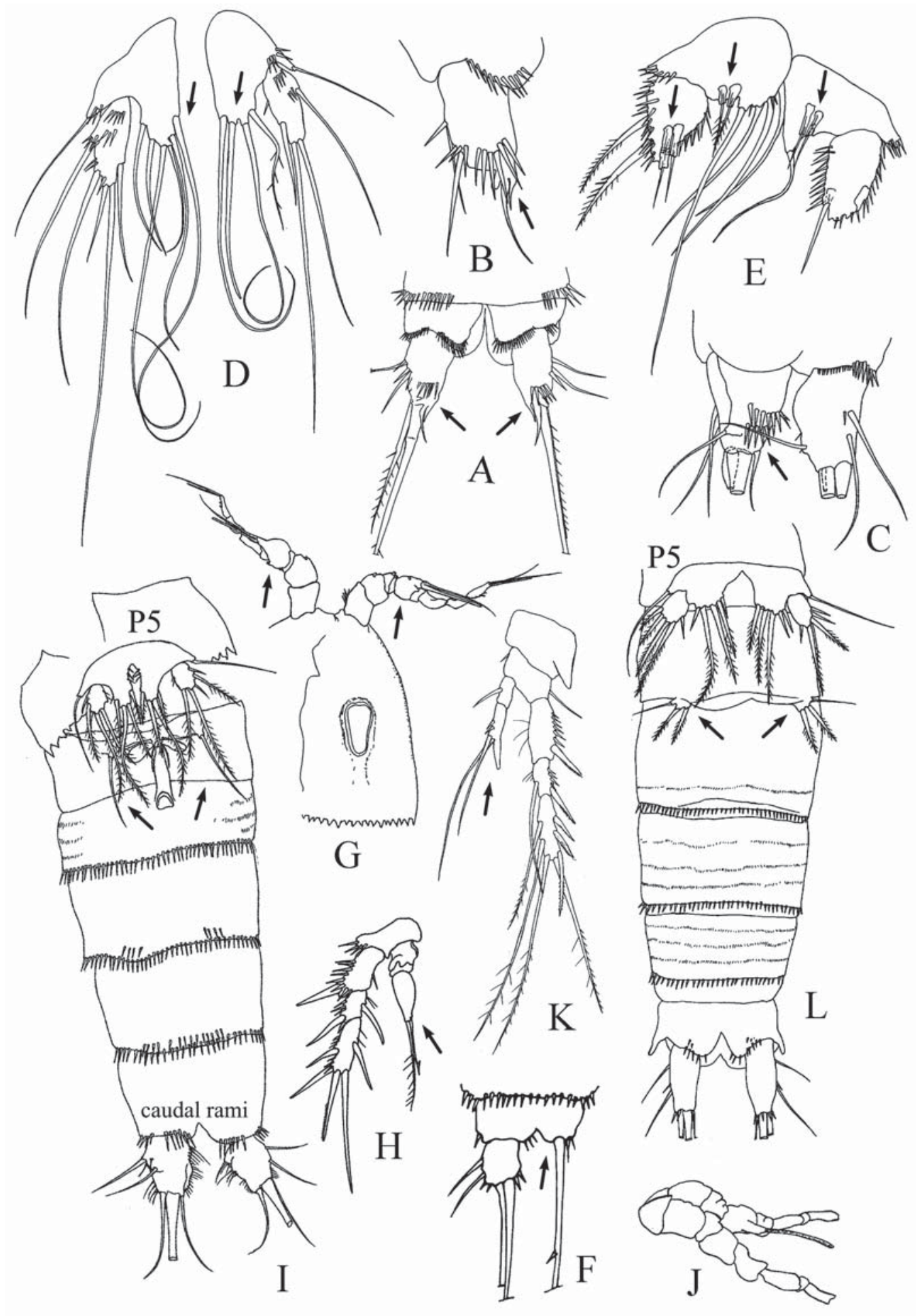


Scott, 1903, collected from an unnamed lake in the basin of the Ozyornaya river; instead of a single row of spinules on the inner side of the caudal rami, a double row of spinules was present along part of the inner side.

\section{Teratology}

In examined water bodies (Glubokoe Lake, lakes in the Pechora River Delta, Lopyu Lake, the Shugor River) species were found with the following phenotypical deviations: 1) asymmetrical structure of the paired organs (swimming legs, rudimentary fifth leg, Fig. 2D, F);2) symmetrical abnormal armature of the fifth pair of legs (Fig. 2E); 3) specimens with attributes of both sexes (transsexual mutations) (Fig. 2G-L).

The frequency of these abnormalities was not stable in studied populations. Asymmetrical structures were rare. Thus, only $0.5 \%$ of $A t$ thyella (Neomrazekiella) nordenskjoldi (Lilljeborg, 1902) species in the Shugor River had a deformed caudal ramus (Fig. 2F).

A massive record (about $70 \%$ of all population) of abnormal Atthyella (Neomrazekiella) northumbrica trisetosa Chappuis, 1929 (Fig. 2E) was made for meiobenthos of the Lopyu Lake.

Two individuals of two different species Pesceus schmeili (Mrazek, 1893) and C. staphylinus (Fig. 2G-L) expressed attributes of both sexes in the water bodies of the Pechora Delta River.

\section{Discussion}

\section{Morphological variability}

According to a previous analyses (Fefilova, 2015) of literature data on freshwater harpacticoids morphology by E.V. Borutsky, 1952 and J.B.J. Wells, 2007 intraspecific and intrapopulational variability is expressed differently in different genera; small interstitial species of the genera Bryocamptus, Maraenobiotus, and Epactophanes is subject to the most remarkable variability of all morphological structures.

The origin of the variability of morphological characteristics in $B$. (A.) cuspidatus, $M$. insularis and $M$. mrazeki may result from the duration of geographical isolation of the species populations in the disjunctive distribution, or from environmental conditions, like temperature.

Diversity of morphological characteristics among populations of C. staphylinus were caused by geographical and environmental factors, particularly due to separation of populations during glaciation cycles followed by differential adaptations by the isolated populations. The most variable characteristics are body size, spinnules

Fig. 2. Morphological features of some harpacticoid copepods. A, B - caudal rami of Bryocamptus (Arcticocamptus) cuspidatus female from Bolshaya Lahorta Lake with atypical internal apical setae; C caudal rami of Moraria insularis female from a lake on Dolgiy Island with double row of spinules in the middle of inner sides; D - abnormalities asymmetric structure of P5 female of Attheyella crassa (G.O. Sars) from Glubokoe Lake; E - abnormal development of setae on P5 of Attheyella (Neomrazekiella) northumbrica trisetosa female from Lopyu Lake; F - asymmetric structure of caudal rami of $A$. (N.) nordenskjoldi from the Shugor River; G-I - intersexual individual (female) of Pesceus schmeili from the Pechora River Delta: $\mathrm{G}$ - antennules of male type; $\mathrm{H}$ - the third leg of male type; I - abdomen (P5 and structure of genital somite of female type; caudal rami of male type); J-L - intersexual individual (male) of Canthocamptus staphylinus from the Pechora River Delta: J, K — antennules and the fourth leg of male type; L — abdomen (P5 of female type).

Рис. 2. Морфологические особенности некоторых исследованных особей гарпактикоид (показаны стрелками). А, В - каудальные ветви самки Bryocamptus (Arcticocamptus) cuspidatus из оз. Большая Лахорта с нетипичным развитием внутренней апикальной щетинки; $\mathrm{C}$ - каудальные ветви самки Moraria insularis из озера на о. Долгий с удвоенным рядом шипиков на середине внутреннего края; D - уродливое асимметричное строение Р5 самки Attheyella crassa (G.O. Sars) из оз. Глубокое; Е уродливое развитие щетинок на Р5 самки Attheyella (Neomrazekiella) northumbrica trisetosa из оз. Лопью; F - асимметричное строение каудальных ветвей у самки $A$. (N.) nordenskjoldi из р. Щугор; GI - самка с признаками самца Pesceus schmeili из дельты р. Печора: $\mathrm{G}$ - строение антеннул как у самца; H - строение ноги четвертой пары как у самца; I - абдомен (Р5 и строение генитального сегмента как у самки; каудальные ветви как у самца); J-L — самец с признаками самки Canthocamptus staphylinus из дельты p. Печора: J, K - строение антеннул и четвертой пары ног как у самца; L абдомен (строение Р5 как у самки, с отклонениями). 
on anal operculum and structure of P5, which are common for the interstitial group of species and appear to be a trend that becomes more noticeable in spatially reduced habitats (Galassi et al., 2009). This may coincide with a high level of intraspecific genetic variability among populations of C. staphylinus. Genetic divergence among the populations showed high values $(>20 \%)$, which divided all populations in separate clades (Fefilova, 2015). High genetic divergence between the populations also has been reported for other copepod species and may be related to reproductive isolation among populations (Lee, Frost, 2002; Chen, Hare, 2008; Garlitzka, 2012).

\section{Teratology}

The reasons for the occurrence of teratology in invertebrates might be different. Origin of abnormalities of copepods can be related to random mutations, expression of genetically unstable features (Pandourski, Evtimova, 2005) or traumas in the postembryonic period of development (Smirnov, 1971) and impact of unfavorable environmental conditions (Alekseev et al., 2016). For C. staphylinus, the asymmetrical armature of the fifth pair of legs is a trait of significant intrapopulational diversity (Lang, 1948). The P5 asymmetry (Fig. 2D) is not described in morphology for Attheyella crassa (Sars, 1863), therefore we attributed this case to manifestation of teratology abnormalities. We suppose the environment is unfavorable in the lake Lopyu because of the prevalence of abnormal individuals in the population of $A$. $(N$.) northumbrica trisetosa. The territory of research in the delta of Pechora River where we found two individuals of harpacticoids with transsexual mutations is polluted with large amounts of oil products (Nikonova, 2015).

\section{Acknowledgments}

We are very grateful to T. Timm (Estonian University of Life Sciences, Centre for Limnology, Tartu, Estonia) for helping to sample harpacticoids in Estonia; L. Arvola, J. Loehr (Lammi Biological Station of Helsinki University, Helsinki, Finland) for managing our work on the Pääjärvi Lake; J. Sarvala (Turku University, Turku, Finland) for consulting; N.M. Sukhikh and V. R. Alekseev (Zoological Institute of RAS, St. Petersburg, Russia) and J.
Gerasimov (Saratov University, Saratov, Russia) for providing samples. A. Glotov (Nenets reservation) for fieldwork assistance in the delta of the Pechora River. Our research was supported by RFBR grants: 17-04-00337-a, 17-04-00027, grant from Russian Geographical Society No 14/2015-R; in frame of the state task: Animal World of the Russian European Northeast under the Agricultural Industry Development and Environmental Changes, No 115012860088.

\section{References}

Alekseev V.R., Fatimah M.Y., Fefilova E.B. 2016. Continental copepod biodiversity in North-Eastern Borneo, Malaysia // Arthropoda Selecta. Vol.25. No.2. P.183197.

Borutsky E.V. 1952. [Fauna of USSR. Crustacea. Vol.3. No.4. Freshwater Harpacticoida]. Moscow: AN SSSR Publ. 424 p. [in Russian].

Chen G., Hare M.P. 2008. Cryptic ecological diversification of a planktonic estuarine copepod, Acartia tonsa // Mol. Ecol. Vol.17. P.1451-1468.

Fefilova E.B. 2015. [Fauna of the European North-East of Russia. Copepods (Copepoda)]. Moscow: KMK Scientific Press. Vol.12. 319 p. [in Russian with English summary].

Galassi D.M.P., Huys R., Reid J.W. 2009. Diversity, ecology and evolution of groundwater copepods // Freshwater Biology. Vol.54. P.691-708.

Garlitzka L., Neretina T., Shepetov D., Mugue N., Bagulei J., Azovsky A. 2012. Cryptic diversity of the 'cosmopolitan' harpacticoid copepod Nannopus palustris: genetic and morphological evidence // Mol. Ecol. Vol.21. P.5336-5347.

Lang K. 1948. Monographie der Harpacticiden. Lund: Hiken Ohlsson. Bd.1-2. 1682 S.

Lee C.E., Frost B.W. 2002. Morphological stasis in the Eurytemora affinis species complex (Copepoda: Temoridae) // Hydrobiologia. Vol.480. P.111-128.

Nikonova A.N. 2015. [Transformation of floodplain ecosystems in the Pechora Delta within the Kumzhinsk gas condensate field (Nenets autonomous okrug)] // Izvestiya Akademii Nauk, Seriya Geograficheskaya. No.5. P.117-129 [in Russian with English summary].

Pandourski I., Evtimova V. 2005. Teratological morphology of copepods (Crustacea) from Iceland // Acta Zoologica Bulgarica. Vol.57. No.3. P.305-312.

Smirnov N.N. 1971. [Fauna of USSR. Crustacea. Vol.1. No.2. Chydoridae of the world's fauna.]. Leningrad: Nauka. 531 p. [in Russian].

Suárez-Morales E. 2015. Class Maxillopoda // H. James, D. Thorp, Ch. Rogers (eds.). Thorp and Covich's Freshwater Invertebrates. Boston: Academic Press. P.709-755.

Wells J.B.J. 2007. An annotated checklist and keys to the species of Copepoda Harpacticoida (Crustacea) // Zootaxa. Vol.1568. P.1-872.

Responsible editor E.N. Temereva 